\title{
Evaluation of Russian Foreign Trade Activities from 2000 to 2013
}

\author{
Natalia Victorovna Kuznetsova ${ }^{1} \&$ Olga Igorevna Sharko ${ }^{2}$ \\ 1. Department of World Economy, School of Economics and Management, Far Eastern Federal University, \\ Russian Foundation \\ ${ }^{2}$ School of Economics and Management, Far Eastern Federal University, Suhanova Str., 8, Vladivostok, 690950, \\ Russian Foundation \\ Correspondence: Natalia Victorovna Kuznetsova, Suhanova Str., 8, Vladivostok, 690950, Russian Foundation.
}

Received: December 20, 2014 Accepted: March 23, 2015 Online Published: May 22, 2015

doi:10.5539/ass.v11n14p259 URL: http://dx.doi.org/10.5539/ass.v11n14p259

\begin{abstract}
The current state of Russian economy determines the necessity of evaluation of foreign trade policy, which is a crucial component of industrial regulation. This formed the purpose of the research - the identifying of the opportunities for intensification of Russia's participation in the regional integration process through a comparative analysis of the development of the foreign trade relations of the Russian regions in the period from 2000 to the present time. Analysis of interregional cooperation of Russian regions showed that there is a trade deficit in most regions. In most regions there is a focus on the export of resources and irrational structure of imports, which promotes the preservation of the inertial scenario of expansion of foreign economic activity of the regions and the country as a whole. The growth of exports is implementedat higher ratescompared to the growth of imports. Consequently, Russian foreign trade, which had a stable export orientation previously, has become even more export-oriented. Russian Federation despite the status of a major industrial power has actually become a mono-cultural exporter. With such high concentration of exports in a small group of commodities and materials to Russia the scope of maneuver into the foreign economic relations significantly narrows and its vulnerability against the negative changes in the world conjuncture greatly increases. In addition, high deterioration of external conjuncture of the energy export was a cause of a number of serious systemic risks for domestic economy and finally may be a cause of deep economic crisis.
\end{abstract}

Keywords: foreign trade activity, export, import, trade balance, foreign economic relations, commodity composition, market conjuncture

\section{Introduction}

Modern methodology of governmental regulation of foreign trade constituted on the basic economic postulates of classical political economy and international trade theory J. Keynes (2007), J. Mill (2007), D. Ricardo (2007), A. Smith (2007) and others.

Recent trends of socio-economic development of Russia, from the aspects of efficiency of foreign policy, were investigated by Russian researchers: N. Obuhov (2011), Sh. Satimov (2010), P. Taranov (2000), V. Shumilov, (2006) and others.

The relationship of the integration processes and foreign trade regulation of the subjects of international relations from the aspect of trade and economic consequences for the national economy is investigated by well-known representatives of the classical theories of international economic integration: M. Allais, (1998), R. Johns, (2000), P. Krugman (2004), G. Myrdal (1958), P. Samuelson (2010) and others.

The research of conceptual and methodological development of the customs union as an isolated individual-specific model of international economic integration was conducted by the founder of the theory of customs unions: B. Balassa (2004), F. List (2005), J. Mid (2000) and others.

Analysis of macroeconomic efficiency of participation of Russia in the integration processes, and the integration of foreign trade within the customs union, in particular, are devoted the researches of scholars such as: S. Borisova (2009), T. Voronina (2005), V. Obolenskii (2011), N. Slyusar (2009).

However, some issues which related to the economic impact of supranational integration mechanism of regulation of foreign trade activities of Russia on the structural and economic performance of foreign trade, were 
hardly investigated in the scientific and economic literature, the cause of it is that the research in this area often have general features.

Identifying the opportunities for enhancing of Russian participation in regional integration processes as a factor to increase country's international competitiveness involves a comparative analysis of foreign trade relations development of Russian regions in the period from 2000 to the present time in the context of intensification the presence of Russian economy in the Pacific Rim industry markets. For this purpose, we made a general analysis of Russian regions' foreign trade activity and the analysis of the commodity structure of their import and export from 2000 to 2013.

This is determined by an objective necessity to assess practically the opportunities of Russian economy, in this case, by foreign trade relations for a reasonable development of different directions of structural transformation of Russian economy through the integration in the Pacific Rim industry markets.

Foreign trade policy is an important component of an industry regulation. Import-export flows, dumping, tariffs, grant-in-aids, and quotas have a significant impact on markets development inland and a formation of their structure.

The trends of country foreign relations in modern terms are largely determined by possible scenarios of its development foreign economic relations. This is especially important in the current economic situation that remains insufficiently stable despite the conspicuous efforts of the government. The value of foreign trade for the country economy steadily increases. One of the main factors in increasing the region competitiveness is a balanced foreign economic policy.

The expansion of export capacity improves the economic situation of many regions. However, due to the structural features of their economy, the foreign economic activity greatly varies by volumes, the exports structure, and the involvement into the foreign economic relations in general.

\section{Methods}

Extensive research involves the use of different research methods, such as abstraction, theoretical modeling, and logical-analytical method. With the help of these methods has been identified special position occupied by foreign trade activities in the socio-economic field.

The methodological basis of the study are also traditional methods specific to the study of international relations of objects, such as the method of comparative analysis, systematic method, which shows the development of relations and cooperation between the two countries, as defined by evolving system, emphasizing its basic elements, cost-effective way, as well as the statistical method.

During the development of a problem and a solution of its main objectives were used a combination of an analytical and heuristic potential of various private methods of studying real economic phenomena and trends that characterize a spatial development of national economy of a country and its regions:economic-statistical grouping, comparative and situational analysis.

These methods give a possibility to determine the range of the most pressing issues currently facing against the foreign economic activity, to trace the genesis of these problems, to identify their theoretical and economic bases.

\section{Results}

General analysis of foreign trade activities of the Russian regions from 2000 to 2013 showed that the volumes and commodity structure of the country is determined by external policies and priorities for economic development. The study showed that the decreasing of a trade balance for an analyzed period is a typical feature of most Russian regions (see Table 1).

Table 1. Russian trade balance, 2000-2013 (million U.S. dollars)

\begin{tabular}{|c|c|c|c|c|}
\hline \multirow{2}{*}{ The region } & \multicolumn{4}{|c|}{ Trade balance } \\
\hline & 2000 & 2005 & 2010 & 2013 \\
\hline Central FD & 16714.60 & 46275.40 & 29902.20 & 57650.43 \\
\hline Belgorod Region & -40.40 & -501.10 & -1496.90 & -943.20 \\
\hline Bryansk Region & -50.30 & -416.60 & -685.70 & -1216.74 \\
\hline Vladimir Region & -46.20 & -64.30 & -518.60 & -916.92 \\
\hline Voronezh Region & 14.20 & 232.70 & 83.50 & 422.56 \\
\hline Ivanovo Region & -132.70 & -104.40 & -427.90 & -577.99 \\
\hline Kaluga Region & -42.90 & -267.90 & -5666.50 & -6957.13 \\
\hline Kostroma Region & 50.50 & 52.40 & 44.50 & 27.48 \\
\hline
\end{tabular}




\begin{tabular}{|c|c|c|c|c|}
\hline Kursk Region & -68.80 & 87.90 & 136.10 & 58.59 \\
\hline Lipetsk Region & 892.60 & 2259.40 & 2648.60 & 2841.50 \\
\hline Moscow Region & -29.50 & -4419.10 & -17465.60 & -24670.37 \\
\hline Orel Region & -38.10 & -61.10 & -776.70 & -507.31 \\
\hline Ryazan Region & 723.50 & -20.00 & -153.00 & -346.30 \\
\hline Smolensk Region & 305.00 & 394.90 & 150.80 & 55.17 \\
\hline Tambov Region & -12.60 & -20.00 & -304.60 & -259.73 \\
\hline Tver Region & -69.20 & -84.20 & -534.10 & -847.64 \\
\hline Tula Region & 511.60 & 1753.80 & 1608.70 & 2294.66 \\
\hline Yaroslavl Region & 677.60 & 156.60 & -48.50 & 752.86 \\
\hline Moscow & 14070.30 & 47296.60 & 53308.10 & 88440.93 \\
\hline Northwestern FD & 5338.60 & 1116.50 & -2966.80 & -7637.44 \\
\hline Republic of Karelia & -926.70 & 815.20 & 1187.20 & 837.06 \\
\hline Komi Republic & 983.50 & 472.10 & 800.10 & 3195.01 \\
\hline Arkhangelsk Region & 665.60 & 905.60 & 5309.60 & 2014.71 \\
\hline Nenets Autonomous Area & - & - & - & -0.68 \\
\hline Vologda Region & 1391.40 & 2699.90 & 3256.60 & 3176.24 \\
\hline Kaliningrad Region & -7246.10 & -2937.00 & -7337.20 & -10629.75 \\
\hline Leningrad Region & 1638.60 & 2842.70 & 5366.50 & 8470.08 \\
\hline Murmansk Region & 462.30 & 980.30 & 1576.70 & 1464.33 \\
\hline Novgorod Region & 207.20 & 463.90 & 581.60 & 549.93 \\
\hline Pskov Region & 30.60 & 74.70 & -1009.60 & -927.49 \\
\hline St. Petersburg & -54.20 & -5201.10 & -12698.50 & -15786.88 \\
\hline Southern FD & 1570.80 & 1474.00 & 660.80 & 6505.72 \\
\hline Republic of Adygeya & -5.40 & -4.50 & -62.60 & -60.12 \\
\hline Republic of Kalmykia & 148.80 & 75.00 & -39.60 & -34.18 \\
\hline Krasnodar Territory & 424.00 & 19.30 & -161.50 & 2232.88 \\
\hline Astrakhan Region & 196.70 & 94.90 & 70.50 & 345.58 \\
\hline Volgograd Region & 617.10 & 1520.80 & 1611.10 & 3011.48 \\
\hline Rostov Region & 189.60 & -231.50 & -757.10 & 1010.09 \\
\hline North Caucasian FD & 259.80 & 930.10 & -310.10 & -892.53 \\
\hline Republic of Daghestan & 109.40 & -58.20 & -281.20 & -669.60 \\
\hline Republic of Ingushetia & -19.00 & 476.50 & -10.70 & -14.73 \\
\hline Kabardino-Balkarian Republic & -5.20 & 35.10 & -46.50 & -38.53 \\
\hline Karachayevo-Circassian Republic & 0.60 & 4.60 & -88.80 & -437.47 \\
\hline Republic of North Ossetia - Alania & -0.30 & 8.70 & 0.90 & -21.55 \\
\hline Chechen Republic & - & - & -1.90 & -25.24 \\
\hline Stavropol Territory & 174.30 & 463.40 & 118.10 & 314.59 \\
\hline Volga FD & 13052.70 & 26166.00 & 35990.10 & 45033.98 \\
\hline Republic of Bashkortostan & 2426.60 & 5976.70 & 8737.30 & 12426.00 \\
\hline Republic of Mari El & 20.00 & 23.10 & 349.80 & 299.28 \\
\hline Republic of Mordovia & -6.10 & -27.90 & -45.40 & -62.61 \\
\hline Republic of Tatarstan & 2627.10 & 8398.00 & 13302.20 & 16009.56 \\
\hline Udmurtian Republic & 882.00 & 201.10 & -18.00 & 591.87 \\
\hline Chuvash Republic & 6.30 & 95.90 & 64.70 & -160.89 \\
\hline Perm Territory & 2076.20 & 2660.20 & 3677.20 & 664.29 \\
\hline Kirov Region & 356.20 & 342.70 & 507.30 & 1609.93 \\
\hline Nizhny Novgorod Region & 540.60 & 659.50 & -11.50 & 2021.02 \\
\hline Orenburg Region & 731.50 & 1281.20 & 1875.80 & -123.74 \\
\hline Penza Region & 19.60 & -11.20 & -29.70 & 5904.28 \\
\hline Samara Region & 2888.40 & 5213.90 & 6303.60 & 4605.63 \\
\hline Saratov Region & 364.10 & 1228.00 & 1199.80 & 1514.58 \\
\hline Ulyanovsk Region & 120.20 & 124.90 & 76.80 & -265.22 \\
\hline Ural FD & 18605.20 & 37829.40 & 51005.90 & 50913.27 \\
\hline Kurgan Region & 115.80 & 23.70 & 47.80 & 299.98 \\
\hline Sverdlovsk Region & 2200.90 & 4423.30 & 5617.40 & 4215.50 \\
\hline $\begin{array}{l}\text { Tyumen Region } \\
\text { including: }\end{array}$ & 8648.70 & 30031.20 & 43110.60 & 20468.40 \\
\hline Khanty-Mansi Autonomous Area - Yugra & - & 11181.00 & 15080.10 & 22384.53 \\
\hline Yamal-Nenets Autonomous Area & - & 401.80 & 257.00 & 1960.86 \\
\hline Chelyabinsk Region & 1274.10 & 3351.20 & 2230.10 & 1584.00 \\
\hline Siberian FD & 9124.20 & 21652.70 & 30340.30 & 26807.80 \\
\hline Republic of Altai & -16.70 & -70.50 & 14.30 & 16.85 \\
\hline Republic of Buryatia & 86.80 & 186.30 & 287.80 & 1099.35 \\
\hline Republic of Tuva & 21.40 & - & -3.20 & 0.18 \\
\hline Republic of Khakassia & 192.80 & 377.50 & 1279.50 & 1231.05 \\
\hline Altai Territory & 92.60 & 538.80 & 87.70 & 206.47 \\
\hline Trans-Baikal Territory & 43.70 & 80.90 & -249.40 & -345.17 \\
\hline Krasnoyarsk Territory & 2983.30 & 5567.70 & 8643.10 & 5872.30 \\
\hline Irkutsk Region & 2404.90 & 2470.10 & 3919.50 & 6986.36 \\
\hline Kemerovo Region & 1685.70 & 4208.80 & 9668.50 & 11639.06 \\
\hline Novosibirsk Region & 201.60 & 346.10 & -390.20 & -563.06 \\
\hline Omsk Region & 760.30 & 6890.20 & 6487.70 & 249.05 \\
\hline Tomsk Region & 668.30 & 1058.00 & 595.20 & 415.38 \\
\hline Far Eastern FD & 2962.40 & 3296.40 & 10906.00 & 15903.54 \\
\hline
\end{tabular}




\begin{tabular}{|c|c|c|c|c|}
\hline Republic of Sakha (Yakutia) & 1050.50 & 2081.20 & 3145.80 & 4543.52 \\
\hline Kamchatka Territory & 92.90 & 108.30 & 565.00 & 525.74 \\
\hline Primorye Territory & 283.10 & -1158.90 & -3629.30 & -5229.69 \\
\hline Khabarovsk Territory & 1186.00 & 2247.10 & 286.20 & 583.20 \\
\hline Amur Region & 41.30 & 50.80 & -125.70 & -25.79 \\
\hline Magadan Region & -37.50 & -60.50 & -21.00 & -155.34 \\
\hline Sakhalin Region & 340.20 & -1424.20 & 10791.20 & 15809.47 \\
\hline Jewish Autonomous Region & 7.50 & -0.70 & -29.00 & -66.30 \\
\hline Chukotka Autonomous Area & -1.60 & 1453.40 & -77.20 & -81.28 \\
\hline
\end{tabular}

Retrieved from: (Russian Federal State Statistics Service, 2014; The Ministry of Economic Development, 2014)

Apparently, the negative balance, i.e. trade deficit, is observed in the majority of the regions.

The trade deficit is not always a negative factor. For instance, during the development of country's economy the growth of imports may meet the demand for goods and services, or cause an increase in price competition. However, in some countries, as a rule, prefer to increase exports, based on the creation of domestic jobs and stimulate demand for goods and services which produced domestically. In this situation, the trade deficit adversely affects the whole economy. In times of economic recession, the country has a particularly strong necessity to create surplus value. This usually happens because higher prices are necessary to pay for imports of the finished goods, but raw materials are exported at low prices.

Table 2 presents the analysis of foreign trade turnover in 2005-2013. Obviously, a gradual decline in growth of exports and imports is observed.

Table 2. The dynamics of a foreign trade turnover, $\%$

\begin{tabular}{cccccccccc}
\hline \multirow{2}{*}{ Region } & \multicolumn{3}{c}{ Export growth } & \multicolumn{3}{c}{ Import growth } & \multicolumn{3}{c}{ Foreign trade turnover growth } \\
\cline { 2 - 10 } & 2005 (to 2000) & 2010 & 2013 & 2005 (to 2000) & 2010 & 2013 & 2005 (to 2000) & 2010 & 2013 \\
\hline Central FD & 198.94 & 67.81 & 47.67 & 222.67 & 163 & 37.44 & 206.66 & 100.38 & 43.07 \\
Northwest FD & 99.18 & 85.12 & 29.97 & 303.11 & 111.88 & 39.45 & 164.04 & 98.12 & 34.89 \\
Southern FD & 88.81 & 84.85 & 72.30 & 191.52 & 133.6 & 18.03 & 122.14 & 105.61 & 46.04 \\
North Caucasian FD & 149.11 & -29.04 & 16.04 & 54.34 & 181.53 & 57.11 & 116.09 & 23.35 & 39.36 \\
Volga FD & 97.7 & 48.22 & 33.08 & 85.08 & 101.03 & 60.02 & 95.78 & 55.82 & 38.09 \\
Ural FD & 102.59 & 42.64 & -1.49 & 95.9 & 116.57 & -9.21 & 101.99 & 49.09 & -2.47 \\
Siberian FD & 124.43 & 47.09 & -9.01 & 73.28 & 84.97 & 1.85 & 115.87 & 52.18 & -7.24 \\
Far Eastern FD & 146.06 & 108.12 & 50.72 & 741.92 & 36.41 & 57.66 & 238.86 & 80.37 & 52.75 \\
\hline
\end{tabular}

In the recent years, the percentage of a foreign trade turnover in Russia's GDP has been reducing on the grounds of slow export diversification and insufficiently competitive positions of Russian manufacturing companies. The slowdown in export growth was due to a slow increase, and in some cases due to lower prices for the majority of exports of fuel and energy products. The import increasing was enhanced by a further expand of demand and rise in investment activity. By the way, until recently, imports increased due to appreciation of the real exchange rate. The reducing of a trade surplus occurred due to faster growth of imports over the export growth.

According to the data, the foreign trade activity in some regions is presented extremely uneven. The highest volume of exports observed in the Central (47.5\%), Volga (13\%), the Urals (12.8), and the North-West (10.2\%) federal districts. Volga Federal District (5.8\%) and Ural Federal District (3.2\%), in turn, cede in this position to Northwestern Federal District (17.9\%). In such circumstances, the federal districts acquire a significant role, which is to coordinate foreign economic activity in some regions, providing a common economic space of the country.

It is important to realize that the impact of foreign trade on the economy of each country does not appear directly but through the strengthening or weakening of the internal factors of economic growth. The value of foreign trade as an indirect factor of an economic growth depends on the overall strategy of this growth. Therefore, in terms of extensive growth, which is achieved by constant efficiency in production and is characterized by tendencies toward economic isolation, the importance of international relations is largely reduced. In this regard, economic growth is fully justified activities of internal factors, as well as through the system of foreign trade surplus supply of goods for export and purchase necessary goods that are not produced in the country.

In contrast to the extensive and intensive type of economic growth based on the increase in scale and quality to improve the culture of production factors, which include improving the means and objects of labor, improving workforce skills, strengthening organizational parameters of production, so that production growth is provided 
mainly by social development countries. Everything that was mentioned claims the intensification of foreign trade relations as one of the most important conditions for its effective implementation.

The analysis of the import-export commodity composition of output by regions of Russian Federation from 2000 to 2013.

The analysis of interregional cooperation of Russian regions shows that most parts of the Russian Federation are characterized by resource orientation of export and irrational structure of import that contribute the conservation of the inertial scenario of foreign economic activity development of Russia and its regions. As a confirmation of this statement we propose to consider more thoroughly the structure of export and import by commodity groups of all Russian regions so far as an essential feature of participation certain industries in the international division of labor is a much higher unit weight of export of these sectors compared to others (see Table 3).

Table 3. The export-import commodity composition by Russian Federal Districts (FD) from 2000 to 2013, \%

\begin{tabular}{|c|c|c|c|c|c|c|}
\hline \multirow{2}{*}{ Region } & \multicolumn{2}{|c|}{ Provisions } & \multicolumn{2}{|c|}{ Fuel-energy products } & \multicolumn{2}{|c|}{ Petro-chemical products } \\
\hline & export & import & export & import & export & import \\
\hline \multicolumn{7}{|c|}{ Central FD } \\
\hline 2000 & 19.855 & 54.892 & 35.362 & 45.219 & 16.735 & 53.390 \\
\hline 2005 & 29.612 & 52.020 & 50.688 & 23.348 & 17.406 & 63.720 \\
\hline 2010 & 22.731 & 48.059 & 47.169 & 13.671 & 22.390 & 68.421 \\
\hline 2012 & 32.791 & 53.392 & 50.900 & 36.016 & 24.465 & 68.601 \\
\hline \multicolumn{7}{|c|}{ Northwest FD } \\
\hline 2000 & 13.265 & 24.841 & 5.803 & 1.765 & 11.777 & 10.262 \\
\hline 2005 & 15.047 & 30.880 & 4.364 & 6.777 & 10.394 & 14.094 \\
\hline 2010 & 12.022 & 27.922 & 7.588 & 2.511 & 11.030 & 11.654 \\
\hline 2012 & 12.621 & 29.702 & 9.009 & 5.060 & 13.012 & 12.587 \\
\hline \multicolumn{7}{|c|}{ Southern FD } \\
\hline 2000 г. & 25.006 & 5.136 & 2.991 & 2.835 & 5.074 & 4.117 \\
\hline 2005 г. & 34.912 & 6.341 & 1.421 & 2.390 & 5.713 & 2.995 \\
\hline 2010 г. & 21.818 & 7.014 & 1.998 & 10.832 & 1.877 & 2.461 \\
\hline 2012 г. & 27.774 & 7.444 & 3.254 & 7.332 & 2.194 & 2.550 \\
\hline \multicolumn{7}{|l|}{ Volga FD } \\
\hline 2000 г. & 5.220 & 3.830 & 19.538 & 34.254 & 34.428 & 7.234 \\
\hline 2005 г. & 4.794 & 3.318 & 13.419 & 31.101 & 38.828 & 4.008 \\
\hline 2010 г. & 3.070 & 2.664 & 11.265 & 7.541 & 32.869 & 4.666 \\
\hline 2012 г. & 6.379 & 2.357 & 12.160 & 14.071 & 39.699 & 6.125 \\
\hline \multicolumn{7}{|c|}{ North Caucasian FD } \\
\hline 2010 & 1.285 & 1.079 & 0.015 & 0.928 & 2.301 & 0.275 \\
\hline 2012 & 1.584 & 1.320 & 0.016 & 0.397 & 2.372 & 0.442 \\
\hline \multicolumn{7}{|l|}{ Ural FD } \\
\hline 2000 & 4.950 & 2.637 & 30.120 & 6.871 & 11.209 & 3.701 \\
\hline 2005 & 2.203 & 1.489 & 20.163 & 21.283 & 10.387 & 2.758 \\
\hline 2010 & 1.323 & 1.024 & 16.488 & 14.077 & 7.664 & 1.666 \\
\hline 2012 & 1.332 & 1.028 & 16.445 & 18.613 & 9.921 & 1.930 \\
\hline \multicolumn{7}{|c|}{ Siberian FD } \\
\hline 2000 & 10.201 & 4.245 & 4.321 & 8.216 & 20.569 & 20.056 \\
\hline 2005 & 4.417 & 3.094 & 6.870 & 12.484 & 16.944 & 10.133 \\
\hline 2010 & 2.746 & 2.094 & 5.469 & 5.644 & 12.350 & 5.710 \\
\hline 2012 & 3.145 & 1.538 & 3.573 & 13.799 & 7.939 & 5.405 \\
\hline \multicolumn{7}{|c|}{ Far Eastern FD } \\
\hline 2000 & 21.218 & 2.085 & 1.863 & 0.846 & 0.169 & 1.020 \\
\hline 2005 & 8.841 & 2.539 & 3.076 & 2.553 & 0.307 & 2.184 \\
\hline 2010 & 21.237 & 2.578 & 4.344 & 1.953 & 0.202 & 1.479 \\
\hline 2012 & 13.965 & 2.768 & 4.610 & 3.481 & 0.328 & 1.922 \\
\hline
\end{tabular}

\begin{tabular}{cccccc}
\hline \multirow{2}{*}{ Region } & \multicolumn{2}{c}{ Timber industry (Wood) } & Ferrous and non-ferrous metals & \multicolumn{2}{c}{ Machine engineering industry } \\
\cline { 2 - 6 } & export & import & export & import & export \\
\hline
\end{tabular}




\begin{tabular}{|c|c|c|c|c|c|c|}
\hline \multicolumn{7}{|c|}{ Central FD } \\
\hline 2000 & 5.570 & 58.241 & 17.173 & 47.775 & 36.278 & 48.517 \\
\hline 2005 & 7.059 & 59.353 & 17.165 & 41.130 & 36.281 & 54.994 \\
\hline 2010 & 6.249 & 59.961 & 17.356 & 42.595 & 38.478 & 62.338 \\
\hline 2012 & 8.610 & 56.975 & 21.945 & 51.818 & 42.982 & 63.752 \\
\hline \multicolumn{7}{|c|}{ Northwestern FD } \\
\hline 2000 & 41.665 & 21.197 & 14.365 & 9.438 & 17.930 & 15.825 \\
\hline 2005 & 38.898 & 27.901 & 15.287 & 17.699 & 19.347 & 19.301 \\
\hline 2010 & 31.237 & 22.988 & 11.755 & 17.093 & 11.603 & 15.760 \\
\hline 2012 & 32.676 & 26.811 & 14.274 & 17.366 & 12.291 & 17.756 \\
\hline \multicolumn{7}{|c|}{ Southern FD } \\
\hline 2000 & 2.070 & 7.836 & 3.921 & 12.407 & 5.058 & 5.869 \\
\hline 2005 & 2.116 & 4.250 & 4.939 & 16.342 & 5.301 & 3.546 \\
\hline 2010 & 1.227 & 4.345 & 3.863 & 11.058 & 2.650 & 2.695 \\
\hline 2012 & 1.223 & 5.160 & 4.357 & 9.791 & 2.751 & 2.146 \\
\hline \multicolumn{7}{|c|}{ Volga FD } \\
\hline 2000 & 10.576 & 5.675 & 5.020 & 16.927 & 19.024 & 11.803 \\
\hline 2005 & 8.889 & 2.760 & 6.414 & 6.728 & 21.889 & 6.749 \\
\hline 2010 & 8.551 & 3.414 & 5.435 & 6.499 & 15.130 & 5.539 \\
\hline 2012 & 10.149 & 3.907 & 5.935 & 6.182 & 21.512 & 5.939 \\
\hline \multicolumn{7}{|c|}{ North Caucasian FD } \\
\hline 2010 & 0.087 & 0.266 & 0.148 & 0.536 & 0.388 & 0.462 \\
\hline 2012 & 0.060 & 0.511 & 0.098 & 0.608 & 0.303 & 0.484 \\
\hline \multicolumn{7}{|c|}{ Ural FD } \\
\hline 2000 & 1.254 & 2.023 & 21.726 & 8.933 & 5.151 & 8.405 \\
\hline 2005 & 2.366 & 2.412 & 25.070 & 4.815 & 5.711 & 3.534 \\
\hline 2010 & 2.835 & 1.543 & 20.697 & 5.293 & 9.451 & 4.474 \\
\hline 2012 & 2.841 & 1.380 & 23.315 & 5.728 & 10.400 & 3.083 \\
\hline \multicolumn{7}{|c|}{ Siberian FD } \\
\hline 2000 & 26.050 & 1.583 & 36.113 & 3.276 & 9.603 & 5.689 \\
\hline 2005 & 27.361 & 0.952 & 28.754 & 2.079 & 8.781 & 3.200 \\
\hline 2010 & 32.633 & 0.994 & 32.092 & 3.044 & 7.505 & 2.687 \\
\hline 2012 & 34.629 & 1.205 & 28.771 & 3.613 & 6.978 & 3.201 \\
\hline \multicolumn{7}{|c|}{ Far Eastern FD } \\
\hline 2000 & 12.804 & 1.133 & 1.679 & 0.878 & 6.956 & 3.342 \\
\hline 2005 & 11.770 & 1.920 & 2.342 & 11.105 & 2.630 & 8.006 \\
\hline 2010 & 10.768 & 2.113 & 1.166 & 4.399 & 1.403 & 2.880 \\
\hline 2012 & 9.705 & 3.028 & 1.377 & 3.967 & 2.596 & 3.365 \\
\hline
\end{tabular}

Retrieved from: (Regions of Russia, 2014)

In 2000, the highest percentage of imports (58.24\%) had timber (wood) in the Central Federal District; and besides the percentage in Moscow is 46.36\% and 6.48 in Moscow region. The least share is to products of fuel-energy complex (45.22\%; Moscow - 33.62\%; Moscow Region - 10.26\%). If we consider the export of the Central Federal District, we observe the highest percentages in the engineering industry $(36.28 \%)$ and the energy sector $(35.36 \%)$. Thus, the wood has the highest percentage of imports, but there are contrasting situations in exports. This sector occupies only $5.57 \%$ of the total exports of the Central District.

In 2005, as in 2000, imports of the Central Federal District prevailed petrochemical products $(63.72 \%$; Moscow $50.7 \%$, Moscow region $-8.17 \%$ of the total share of imports petro-chemical products in the Central Federal District). However, there were large variations in exports. While in 2000 in total exports dominated engineering industry, in 2005, the highest share occupied by the production of fuel and energy complex (50.69\%; Moscow $50.54 \%$ ). Significant growth was $15.33 \%$, while the machine-building industry has not increased its share in total exports. The smallest share of exports in 2000 took the timber industry (wood).

Minor changes were observed in the structure of exports and imports of the Central District in 2010, the sector occupied the same position in 2012. Growth in imports of petro-chemicals and chemical industry amounted to $4.88 \%$. 
Likewise, the percentage of fuel-energy products has increased to $36.02 \%$. The growth of fuel-energy products $(3.73 \%)$ is also observed in the export structure. Furthermore, the share of wood was $8.6 \%$ in export (growth to $2.35 \%$ compared to 2010 ).

After analyzing each sector separately, we make the following statements: import prevailed almost over all segments in 2000 but the ratio has begun to change to 2012, and we may observe the overall growth of export; in our opinion, the most imported sector is petro-chemical products, then - machine-engineering industry; the most exported sector is fuel-energy products than - machine-engineering industry.Therefore, by analyzing the data, we may highlight that machine-engineering industry is a significant sector in both export and import. The worth noting is that the whole "picture" has not changed in the period from 2000 to 2012 in the Central FD: the export and import leaders have remained their positions increasing their share.

We consider the Northwestern FD. The largest share of imports was observed in St. Petersburg - 17.42\%, Kaliningrad region $-4.15 \%$, Leningrad region $-1.84 \%$. A smaller share is in the products of fuel and energy complex $(1.76 \%$ of the total share of imports). In exports, the largest share was forest $-41.67 \%$. A small proportion as in the import content of exports of goods energy sector was $5.8 \%$.

The situation in the foreign trade did not change a lot in 2005. The most and least significant sectors in import remained provisions $(30.88 \%)$ and fuel-energy products $(6.78 \%)$ respectively. The sectors remainin the same positions in export; only the share changed. Thus, timber was the most important sector; its share decreased by $2.77 \%$ compared to 2000 . The lowest share was to fuel-energy products $(4.36 \%)$.

The situation did not change a lot in 2010 and 2012 in the Northwestern FD. Thereby, the export-import positions of sectors have not changed in the period from 2000 to 2012. The most important sector in the Northwestern Federal District is the food and the timber, because these industries occupy a large part of the total imports of the Northwestern Federal District (more than 20\%). The minor sector is the products of fuel-energy complex. The share of this sector has not exceeded $6.7 \%$ over entirely reviewed period. The indisputable leader of export is timber (more than $30 \%$ of the total exports in the reviewing period). The lowest share, as in import, is to the products of fuel-energy complex. The development of this industry has not kept up other sectors in the Northwestern FD.

We consider the Southern FD. In 2000 ferrous and non-ferrous metals prevailed in import $(12.41 \%$; Rostov Region $-6.14 \%$, Krasnodar Territory $-4.35 \%$ ). The lowest share was to fuel-energy products $-2.84 \%$. In export operations provisions prevailed in 2000 with a share of $25.01 \%$; the least share was to timber $-2.07 \%$.

In 2005 , as in 2000 , ferrous and non-ferrous metals prevailed in import but with a share of $16.34 \%$ (the growth was $3.93 \%$ compared to 2000). The lowest percentage was to fuel-energy products $-2.39 \%$. Provisions had the highest percentage (34.91\%) in the export structure of the Southern FD. The least share was to fuel-energy products $-1.4 \%$.

The sectors taken the major and minor position have not changed in 2010 and 2012.

Thus, throughout the period considered most imported industries include ferrous and nonferrous metals. In the first part of the reviewing period (2000 and 2005) the lowest share is to the products of the fuel-energy complex, and in the second part (2010 and 2012) - petro-chemical products. The most important sector in the export is provisions. The least share in export was to fuel-energy products in 2005, and timber - in other reviewing years.

We consider Volga FD. Fuel energy products prevailed in the Volga FD import in $2000-34.25 \%$. The least share was to provisions $(3.83 \%)$. The petro-chemical products clearly prevailed in the export with the share in $34.43 \%$. The lowest share is taken by ferrous and non-ferrous metals $-5.02 \%$.

Fuel-energy products prevailed in the import of Volga FD in 2005 with a share of $31.1 \%$. The least percentage was to timber $-2.76 \%$. In addition petro-chemical products also occupy the small part from the overall import. However, petro-chemical products prevailed in export with a share of $38.83 \%$. The least share was to provisions $(4.79 \%)$.

As in the previous years, products of the fuel-energy complex prevailed in the import of Volga FD in 2010 (7.54\%). The share of the sector decreased by $23.56 \%$ compared to 2005 . It is also worth to note the percentage of ferrous and non-ferrous metals in the import in $2010(6.5 \%)$. The least share was to provisions $-2.66 \%$. Import of timber took not a big part of the total import - 3.41\%. As in the previous year products of the petro-chemical industry prevailed in the export in 2010 (32.87\%). The least share was to provisions $-3.07 \%$.

Products of fuel-energy complex prevailed in the import of Volga FD in 2012 with a share of $14.07 \%$. The smallest part has remained for provisions. The percentage of petro-chemical products in the export structure has 
increased by $6.83 \%$ and reached $39.7 \%$. The least share is to ferrous and non-ferrous metals $(5.94 \%)$ in the export.

Thus, on the whole reviewing period the most imported industry has been the products of fuel-energy complex. Provision has taken the least percentage of the total import and only in 2005 the most "non-imported" industry has been timber. The most exported sector, undoubtedly, has been the production of the petro-chemical industry. The most "non- exported" industry has been ferrous and non-ferrous metals in 2000 and 2012, and provisions in 2005 and 2010.

We consider the North Caucasian FD. Provision prevailed in the import of the North Caucasian FD in 2010 with a share in $1.08 \%$; the smallest part was to timber $(0.27 \%)$. Provision also prevailed in the export $(1.29 \%)$, and the least part was to the fuel-energy production $(0.12 \%)$.

Provisions also prevail in the import of the North Caucasian FD in2012 with a share of $1.32 \%$; the least percentage is to fuel-energy production $(0.4 \%)$. Likewise, provision prevails in the export $(1.58 \%)$, and fuel-energy production has the lowest percentage $-0.02 \%$.

Therefore, both the most imported and exported industry is provision. Moreover, there was a not big change in the weighting factor in the period from 2010 to 2012. Thus, we may conclude that the North Caucasian FD is one of the least developed Russian districts in foreign trade relations.

We consider Ural FD. Ferrous and non-ferrous metals have the biggest part in the import structure of Ural FD in $2000-8.93 \%$. Machine engineering industry with a share of $8.41 \%$ is worth to be highlighted in the import of the reviewing district. The smallest percentage is to timber $(2.02 \%)$. The fuel-energy production prevails in the export (30.12\%), and the least part is to timber (1.25\%) in the export of Ural FD.

If we look through the following years, then we will detect that the positions of sectors did not change in 2005 , 2010 , and 2012. Thus, the most imported industry was fuel-energy production with a share of $21.28 \%$ in 2005 , $14.07 \%$ in 2010 , and $18.61 \%$ in 2012 . The sector decreased its share by $7.21 \%$ in $2010 \$$ the growth was $4.54 \%$ compared to 2010. The least part of the import was to provision with a share in 1.49 in 2005, $1.02 \%$ in 2010, and $1.03 \%$ in 2012 . We may notice that the weight factor did not undergo the significant changes in the reviewing period. Ferrous and non-ferrous metals prevail in the export of Ural FD with a share in $25.07 \%$ in $2005,20.7 \%$ in 2010 , and $23.32 \%$ in 2012 . The least percentage is to provision $-2.2 \%$ in $2005,1.32 \%$ in 2010 , and $1.33 \%$ in 2012. The worth noting that there was not significant changes in the weight factor of provision export in the period from 2005 to 2012 .

Thus, the most imported sector is fuel-energy production (more than $14 \%$ of the total import of Ural FD from 2005), and the least imported sectors are timber and provision (the weight factor was less than $2.7 \%$ in the whole reviewing period from 2000 to 2012).The most exported industries are fuel-energy production and ferrous and non-ferrous metals (the sector of fuel-energy production was the leader only in 2000 , the sector of ferrous and non-ferrous metals took leading position in other years). The least exported industries are provision and timber. In addition, in the provision sector we may highlight a stable decline of the weight factor in the total export of the Ural FD but the share of timber has begun to increase thought did not exceed $2.8 \%$ of the total export of the district.

We consider Siberian FD. The petro-chemical production prevailed in the import of Siberian FD in 2000 $(20.06 \%)$. The least share was taken by timber $-1.68 \%$. The sector of ferrous and non-ferrous metals was the most important industry in the export $(36.11 \%)$. The significant share was also taken by petro-chemical production $(20.6 \%)$. The least percentage was fuel-energy production $(4.32 \%)$ in the export. Machine engineering industry also took not a significant share in the export of Siberian FD (9.6\%).

The fuel-energy production prevailed in the import in 2005 with a share of $12.48 \%$. The import of petro-chemical production was worth to be highlighted. Its share was $10.13 \%$. The least percentage was to timber $(0.95 \%)$. The sector of ferrous and non-ferrous metals prevailed in the export in 2005 (28.75). Timber also occupied a big share of export $-27.36 \%$. The least part was taken by a provision with a share of $4.42 \%$.

The production of the petro-chemical industry prevailed in the import of Siberian FD in 2010 (5.71\%). It should be noted the import of fuel and energy sector with a share of 5.64\%, which was reduced in comparison with 2005 by $54.2 \%$. That sector was a leader in 2005 . The decline of the sector's share was $6.84 \%$. Wood occupies the smallest part of the total import share (32.63\%). The sector of ferrous and non-ferrous metals was also an important industry with a share of $32.09 \%$. The least part of the export of Siberian FD was occupied by provision $(2.75 \%)$. 
Fuel-energy production prevails in the import of Siberian FD in 2012 with a share of $13.8 \%$ (again this industry takes a leading position with the increase by $8.16 \%$; the growth has been $144.68 \%$ compared to 2005 ). The least part is to timber $-1.21 \%$ (the growth of its share is $0.26 \%$ compared to 2005 ). Timber has the biggest part of the export in Siberian FD in 2012 (34.63\%). The minors are provision (3.15\%) and fuel-energy production (3.57\%).

In the provision import we notice the following tendency: there is a decline in its share from $4.25 \%$ to $1.54 \%$ in a reviewing period from 2000 to 2012 . The decrease is $2.71 \%$. The decline of its share was $1.15 \%$ in 2005 and $1 \%$ in 2010. The decrease of share provision in export was observed from 2000 to 2010 . We may note the growth of its share in the export of Siberian FD to 3.15\%.

The peak of fuel-energy production import was $13.8 \%$ in 2012, and the lowest part was $5.64 \%$ in 2010. If we take into consideration the previous years, we will note that its share was $12.48 \%$ in 2005 and the sharp decline to $6.84 \%$, in 2010 . In the fuel-energy export the peak was $6.87 \%$ in 2005 . Further, we may notice the decrease of its share in the export of Siberian FD to $3.57 \%$ in 2012.

We may highlight the decline of the petro-chemical production share in the import of Siberian FD by $14.65 \%$ from 2000 to 2012. We may observe the same tendency in the export.

Thus, the leading positions in import are taken by petro-chemical production and fuel-energy production in the period from 2000 to 2012. The less developed sector is timber. The leading position in export, on the contrary, is taken by timber. The less developed export sectors are provision and fuel-energy production (the last one is the leader in the import). Therefore, if we take into consideration the whole "picture" of export and import, we may note that Siberian FD has more an export component than an import one.

We consider Far Eastern FD. Machine-engineering industry prevail in the import of Far Eastern FD in 2000 (3.34\%). The least parts of the import are taken by fuel-energy production $(0.85 \%)$ and the sector of ferrous and non-ferrous metals (0.88\%). Provision is a major of export in Far Eastern FD (21.22\%). A significant part of the export is also taken by timber $-12.8 \%$. The minor industries of export in Far Eastern FD are petrochemical production $(0.17 \%)$ and the sector of ferrous and non-ferrous metals $(1.68 \%)$.

The sector of ferrous and non-ferrous metals was the most important industry in the import of Far Eastern FD in $2005-11.11 \%$. The high percentage was also taken by machine-engineering industry $-8.01 \%$. The increase in the machine-engineering industry was $4.67 \%$ compared to 2000 , and the growth was $139.82 \%$. The least share was taken by timber (1.92\%). Compared to 2000 , there was not any industry that took less than $1 \%$ of import in 2005. Timber was the major in export in 2005 with a share of $11.77 \%$. The growth of its share was declined by $1.03 \%$. The high percentage was also taken by provision $-8.84 \%$. The growth of its share fell by $12.38 \%$. The least share was to petro-chemical production $(0.31 \%)$.

The sector of ferrous and non-ferrous metals prevailed in the import of Far Eastern FD in 2010 (4.4\%). We can note that the imports of represented sectors noticeably decreased. So, the import of the sector of ferrous and non-ferrous metals decreased by $6.71 \%$ compared to 2005 . The minors of the import were petro-chemical production (1.48\%) and fuel-energy production (1.95). The major in export was provision (21.24\%) in 2010. The least developed sector in export of Far Eastern FD was fuel-energy production (0.2\%).

The following industries were the leading in the import of Far Eastern FD in 2012: the sector of ferrous and non-ferrous metals (3.97\%), fuel-energy production (3.48\%), machine-engineering industry $(33.7 \%)$, and timber (3.03\%). The minor of the import was petro-chemical production $(1.92 \%)$. The leading position in the export was taken by provision (13.97\%) in the 2012; and the least share was to petro-chemical production $(0.33 \%)$.

Therefore, the most imported industry of Far Eastern FD is the sector of ferrous and non-ferrous metals. However, the share of its sector does not take a significant part of the total import, so, all represented industries do not have a great value in the import of Far Eastern FD. Another situation was in export structure. The most exported industry of Far Eastern FD is provision (more than $8.9 \%$ of the overall exports). We also would like to specify timber sector (more than $9 \%$ of the overall export; even though the share of the sector have begun to decrease). The least exported sector has always been the petro-chemical production (less than $0.5 \%$ of the reviewing period from 2000 to 2012).

Thus, the increasing of foreign trade volumes occurred due to export and import. Nevertheless, the growth of export compared to import occurred by higher rates. In this case, Russian foreign trade having had a stable export orientation earlier has become even more export-oriented.

At the same time, a sharp Russian reorientation to a trade with a developed countries, making Russian Federation too dependent on their trade policies - on the one hand, and the continued retention of Russian industrial production - on the other hand, have had a mixed impact on the industrial structure of foreign trade, mainly 
export, further strengthening its resource orientation. Furthermore, the increasing share in the export structure of raw resources occurred due to the steady export reduction of the industrial goods.

The main reason for the industrial goods export reduction has been a weak development of production potential of the sector and, as a consequence, low competitiveness.

The structure of Russian import formed under the influence of the solvent demand and the decline in production is far from the perfection. Nevertheless, import made a significant contribution to a mitigation of social problems, providing a domestic market saturation of consumer goods. Currently, the percentage of import in the country consumed food is about $60 \%$.

Russian Federation, despite the status of a major industrial power, has actually become a monocultural exporter: three kinds of energy carrier - oil, oil products, and natural gas - now provide $62-63 \%$ of total export of goods against $40 \%$ in 1994 and $45 \%$ in 1997. There are $2 / 3$ of all sales are on the 5 basic positions; and there are $3 / 4$ of the total export are on 10 leading positions which are presented by energy source, metals, precious stones, and round wood.

With such a high concentration of exports in a small group of commodities and materials, to Russia the scope in foreign economic relations significant narrows and the Russian vulnerability increases to negative changes in the world conjuncture. In the case of energy export, a sharp deterioration of the external environment poses serious systemic risks for a domestic economy and may lead to a deep economic crisis.

Started an essential drop in the world prices for fuel and raw materials, sharply reduced the government revenue from export, led to a deterioration of an international balance of payment, the growth of foreign liabilities that aggravate the problems established in the foreign economic sphere as well as the economy of the country entirely. In these consequences, the necessity the restructuring of the entire system of organization and management of foreign economic activity has occurred.

Apparently, due to the resource economic orientation a number of regions does not efficiently use their innovative possibilities of foreign economic activity development. In this regard, it is important to move away from the resource export and provide conditions for an export of high technology products and resources.

The main task of Russia in the beginning of the XXI is the restructuring and modernization of the economy, as well as diversification of domestic exports by products of industries, especially high-tech industry.

One of the most crucial objective of foreign economic strategy on federal and regional levels is the growth of high technology products in the export structure that lead to the enhancing of the country's status in the world economy. If the strategy for achieving the innovative development and diversification of the economy will be really implemented, the country has the possibility of effective usage of its intellectual potential in the interests of the national economy, and participates in the globalizing world economy. However, it is obvious, that Russia will not soon be able to completely get away from the economic scenario based on the development of energy resources, and it is clearly demonstrated by the current commodity structure of exports, which is based on energy products.

One of the factors limiting the enhancement of export structure in the direction of increasing the share of finished and high technology production is low competitiveness of different domestic products that highlight the objective of its improvement through the enhancement of innovative activity of scientific organizations.

The structure of Russian export that based on fuel and raw materials more and more diverge with the trends of the world trade development grows mainly because of manufacturing industry products, especially high-tech products, the growth rate of which are particularly high.In long terms we consider a further increasing of the mentioned group of products shares in the world export as the expanding use of resource-saving technologies in the developed countries; the insertion into the circulation the various alternative energy sources, artificial substitutes and secondary material may slow even more the growth of fuel and raw sector of the world market that limit the perspectives of the appropriate Russian export. At saving this structure, the increasing of export volumes cease to be the source of economic growth and becomes a factor of its moderation. It means that in current trends the further increase in export of raw materials and energy resources will not cover the increase in imports of goods, providing final consumption.

In this regard, it is necessary that for each region were developed the programs to increase the share of finished goods with a high value added and programs to rationalize the import structure that should contribute the technology modernization of all region's economies. 
The inclusion of the Russian regions in the international labor division is currently taking place in the conditions of the global process of reproduction, and not part of the national economy. However, there are also a number of diversities between regions on the aspects of integration into the world economy, which has results of significant differentiation for external factors for the purpose of reproduction of the territorial resources. It is due to the regional economic position and indicators such as export potential, diversification of export production and services, investment attractiveness, the level of demand.

The main problem is that, despite the obvious necessity of protectionism policy, Russia cannot adequately protect the domestic markets because of the strong dependence on trade policy of leading countries and because of a lack of production capacity for import substitution of import goods and for the growth of exports of manufacturing industry.

Nowadays, the system of protectionism in Russia is at the beginning stage of development, the usage of non-tariff regulation mechanisms are not fully involved and still poorly perform the function of protection of the domestic market.

\section{Discussion}

The features of national economies development and their integration into the world economy are reflected in the theories of the classical school of B. Ohlin, M. Porter, D. Ricardo, A. Smith, E. Heckscher (Anthology of Economic, 1993), questions of foreign economic relations and enhancement of Russian foreign trade activity and its regions are considered in the studies of A. Arkhipov (2005), A. Basenko (2012), L. Vardomskiy (2008), T. Gogoleva (2010), I. Dumoulin (2008), I. Ivanov (2008), V. Obolenskiy (2008).

In the scientific literature, the research of various problems of region economy is carried out to assess the economic potential of Russian region that is the basis of its development strategy. The study of this problem is reflected in works of A. Granberg (2001), S. Suspitzin (2005), issues of regional policy are noted in the works of V. Ovchinnikov (2008), V. Leksin (2012), A. Shvetzova (2006), the factors of regions' territory competitiveness and analysis of interregional differentiation and construction of ratings of socio-economic development are noted in the studies of S. Baranov and T. Skufina (2005), and other authors.

The problems of region foreign economic potential are reflected in the works of A. Anenkova (2008), G. Gutman (2001), A. Miroedov, A. Marshalova, A. Novoselova (2010), K. Pavlov (2009).

The topicality of the investigated problem consists of the lack of effective mechanisms of foreign economic cooperation and innovative complex in the regions that retains a high level of resource dependence, low investment attractiveness and competitiveness of Russian regions in the world market.In a global economic crisis, the solution of the problems that is stated as the enhancement of foreign economic activity and acceleration of innovative development of Russian regions' economies is becoming more actual.

The escalation of this problem shows the relevance of searching the new theoretical approaches, methods, and mechanisms to ensure the effective foreign economic activity development of Russian regions. A foreign economic activity of the regions should be focused on the solving the urgent problems of increase the export of high technology products, advanced technologies, and the technical services. The meeting these challenges requires an effective interaction of foreign economic complex and innovative system of the region. The important note is that these problems are not developed enough that actualizes the need for further in-depth analysis that may be done after the assessment methods of export potential of the areas of different degrees of localization, which we made.

\section{Conclusion}

We should then learn that foreign trade is already becoming one of the most important and potentially - the most important element of the regional economy that can provide a determinant influence on the long-term prospects of the latter.

Achieved to the current time the level of Russian foreign economic cooperation, as well as the degree of influence of foreign trade on economic development could be much higher in creating the premises for more active involvement in the international division of labor of the regions of the country having indisputable comparative advantages.

In many regions we observed a negative balance, i.e. trade deficit, amid the slowing growth in a foreign trade turnover. In the recent years, the share of foreign trade turnover in Russia's GDP reduces in a result of slow export diversification and insufficiently strong competitive positions of Russian manufacturing companies. 
Russian foreign trade, which had a stable export orientation previously, has become even more export-oriented. At the same time, a sharp Russian reorientation to a trade with a developed countries, making Russian Federation too dependent on their trade policies - on the one hand, and the continued retention of Russian industrial production - on the other hand, have had a mixed impact on the industrial structure of foreign trade, mainly export, further strengthening its resource orientation. Furthermore, the increasing share in the export structure of raw resources occurred due to the steady export reduction of the industrial goods.

The evaluation of the export structure by aggregated commodity groups characterizes Russian exports substantially as external supplies of mineral products and its derivatives, metals, and precious stones. A minor proportion of export with a deep level of processing is presented in a limited format. The negative aspect of Russian exports is the deterioration of its commodity structure in terms of foreign economic competitiveness which has a negative impact on the level and pace of development of the economic system as the whole.

\section{Acknowledgments}

The authors acknowledge receiving support from state-funded research program of Russian Ministry of Education and Science. The results of this research were achieved within the frameworks of the governmental assignmentof Russian Ministryof Education and Science in the sphere of scientific research during the researching assignment \# 26.1478.2014/K "The structural transformation of Russian Economy through the integration installation in the industrial markets of Asia-Pacific Region"

\section{References}

Allais, M. (1998). Terms of efficiency in the economy (p. 299). Moscow: Science and Society.

Annekova, A. A. (2008). Evaluation of the external economic potential of the regional economy: theoretical and methodological approaches. Regional economy: theory and practice, 17(74), 42-46.

Anthology of Economic Classics: Petty, Smith, Ricardo. (1993, p. 540). Moscow: Nauka.

Arkhipov, A. U. (2005). Foreign economic activity of Russian regions in the context of globalization. Economic bulletin of the Rostov state university, 1(3), 82-88.

Balassa, B. (2004). Economical integration. Economic Theory (pp. 220-232). Moscow: Infa-M.

Baranov, S. (2005). Analysis of regional disparities and the construction of the ratings of Russian regions. Problems of Economics, 8, 54-71.

Basenko, A. (2012). Liberalization as a global period of theorizingthe state regulation of the economy. Financial Studies, 2(35), 23-37.

Borisova, S. N. (2009). Aspects of Custom Union formation of Republic of Belarus, Republic of Kazakhstan and Russian Federation. Public and private international law, 6, 6-8.

Dumoulin, I. I. (2008). Foreign economic relations of Russia. Achievements and Challenges. Russianforeigneconomicbulletin, 7, 45-64.

Gogoleva, T. (2010). Methods of assessing the efficiency of the foreign policy of the state: an institutional approach. National interests: priorities and security, 7(64), 17-25.

Granberg, A. G. (2001). Strategy of territorial socio-economic development of Russia: from idea to realization. Problems of Economics, 9, 15-27.

Gutman, G. V. (2001). Management of regional economy (p. 176). Moscow: Finance and Statistics.

Ivanov, I. D. (2008). Foreign economic relations in the domestic reproduction. Russian foreign economic bulletin, $8,25-37$.

Johns, R. (2000). The relationship between the factors and the Heckscher-Ohlin's theorem. Milestones of economic thought, B. 6. p. 236-247. Moscow: TEIS.

Keynes, J. M. (2007). The General Theory of Employment, Interest and Money (p. 957). Moscow: Eksmo.

Krugman, P. R., \& Obstfeld, M. (2004). International Economy: theory and policy (p. 831). StP.: Piter.

Leksin, V. (2012). Reforms and regions. Systematic analysis of the reform process of the regional economy, development of federalism and local self-government (pp. 10-24). Moscow: Lenand.

List, F. (2005). National System of Political Economy. National System of Political Economy. Anthology (pp. 23-258). Moscow: Europe.

Marshalova, A. S. (2010). Competitiveness and municipal development strategy. Region: Economics and 
Sociology, 3, 219-236.

Mid, J. (2000). Theory of Custom Unions. Milestones of Economic Thought (pp. 705-717). Moscow: TEIS.

Mill, J. S. (2007). Principles of political economy with some of their applications to social philosophy (p. 1037). Moscow: Eksmo.

Myrdal, G. (1958). World Economy: problems and perspectives (p. 555). Moscow: Publisher of foreign lit.

Obolenskii, V. P. (2011). Russia in the Customs Union and WTO: new aspects of trade policy. World Economy and international relations, 12, 22-30.

Obolenskiy, V. P. (2008). Evaluation of the Russian economy competitiveness. Russian foreign economic bulletin, 4, 15-24.

Obuhov, N. (2011). Foreign trade and tariff policy. Economist, 8, 80-89.

Ovchinnikov, V. N., \& Kolesnikov, U. S. (2008). Silhouettes of regional economic policy in the South of Russia (p. 176). Rostov-on/D : SFU.

Pavlov, K. V. (2009). Foreign economic aspect of management of regional economic performance. Regional economy: theory and practice, 20(113), 12-19.

Regions of Russia.Socio-economic indicators. Russian Federal State Statistics Service. (2014, December 12). Retrieved December 23, 2014, from http:/www.gks.ru/wps/wcm/connect/rosstat_main/rosstat/ru/statistics/ publications/catalog/doc_1138623506156

Ricardo, D. (2007). Principles of Political Economy and Taxation (p. 953). Moscow: Eksmo.

Russian Federal State Statistics Service. (2014, December 12). Retrieved December 12, 2014, from http://www.gks.ru

Samuelson, P. (2010). Economics. Moscow: Williams, p. 1358.

Satimov, Sh. (2010). Foreign trade and tariff policy as a factor of social stability. Society and Economy, 7-8, 232-241.

Shumilov, V. M. (2006). Comments for the Law "The basis of state regulation of foreign trade". Foreign trade law, 2, 17-19.

Shvetzov, A. (2006). Liberalization of regional policy. Problems of Economics, 7, 65-78.

Slyusar, N. (2009). Customs Union of three members. Proceedings of Industry, 39, 7-8.

Smith, A. (2007). An Inquiry into the Nature and Causes of the Wealth of Nations (p. 956). Moscow: Eksmo.

Suspitzin, S. (2005). Problems of prognostication. Barometers of common regional position, 2, 27-34.

Taranov, P. V. (2000). Transformation of national interests in transition economies of Russia (theory and methodology) (p. 220). Rostov on/Done: Publisher RGEU RINH.

The Ministry of Economic Development of the Russian Federation. (2014, December 12). Retrieved December 12, 2014, from http://economy.gov.ru/minec/main

Vardomskiy, L. B., \& Skatershchikova, E. E. (2008). Foreign economic activity of Russian regions (p. 448). Moscow: KNORUS.

Voronina, T. V. (2005). Globalization - the highest form of internationalization. Finance and Credit, 11, 20-25.

\section{Copyrights}

Copyright for this article is retained by the author(s), with first publication rights granted to the journal.

This is an open-access article distributed under the terms and conditions of the Creative Commons Attribution license (http://creativecommons.org/licenses/by/3.0/). 